\title{
The evaluation of ecological status in Tunca (Tundzha) River (Turkish Thrace) based on environmental conditions and bacterial features
}

\author{
Pınar Altınoluk Mimiroğlu' ${ }^{\circledR}$, Belgin Çamur Elipek ${ }^{2}$, Halide Aydoğdu ${ }^{3}(\mathbb{D}$
}

Cite this article as:

Altınoluk Mimiroğlu, P., Çamur Elipek, B., Aydoğdu, H. (2020). The evaluation of ecological status in Tunca (Tundzha) Tiver (Turkish Thrace) based on environmental conditions and bacterial features. Aquatic Research, 3(2), 98-109. https://doi.org/10.3153/AR20009

${ }^{1}$ Trakya University Technology Research and Development Centre, 22030, Edirne, Turkey

${ }^{2}$ Trakya University Faculty of Science, Department of Biology, 22030, Edirne, Turkey

${ }^{3}$ Trakya University Arda Vocational School, 22100, Edirne, Turkey

ORCID IDs of the author(s): P.A.M. 0000-0002-8524-0972 B.Ç.E. 0000-0002-0954-8967 H.A. 0000-0002-1778-2200

Submitted: 18.02 .2020

Revision requested: 02.03 .2020

Last revision received: 10.03 .2020

Accepted: 17.03.2020

Published online: 21.03 .2020

Correspondence:

Pınar ALTINOLUK MíMíROĞLU

E-mail: pinaraltinoluk@trakya.edu.tr

\begin{abstract}
It is inevitable that the running waters which are used for a lot of different activities like fishing, irrigation, domestic water usage are under threat because of the settlements, industrial or agricultural activities. To provide the sustainable usage of these ecosystems we have to know their current features and their balance under changing environmental conditions. In the present study, the ecological status of Tunca (Tundzha) River which is located on Turkish Thrace was evaluated based on environmental conditions and bacterial features of the river. For this aim, the research has been carried out at 5 different stations in the river between October 2010 and September 2011 at monthly intervals. Some environmental conditions (temperature, dissolved oxygen, $\mathrm{pH}$, conductivity, salinity, chloride, turbidity, hydrogen sulfide, magnesium, calcium, total hardness, $\mathrm{NO}_{3}-\mathrm{N}$, $\mathrm{NO}_{2}-\mathrm{N}$, sulfate, orthophosphate, suspended solid substances, biological oxygen demand) and bacterial features (total coliform, fecal coliform, and Escherichia coli bacterial abundances) were examined performing at the same time samplings. Consequently, it was determined that the water quality of Tunca River has proper physicochemical conditions allowing surviving of living things, but bacteriological findings belonging to the river was not found proper for direct use of water by human. Also, the correlations were evaluated between the obtained environmental features and the bacteria by using Spearman's index. While positive correlations were found between TMAB density and some environmental parameters (water-air temperature, EC, magnesium, nitrate nitrogen, sulfate, o-phosphate, and suspended solids); negative correlations were found between TMAB density and the other parameters ( $\mathrm{pH}$, hydrogen sulfide, calcium, total hardness, and $\mathrm{BOD}_{5}$ ).
\end{abstract}

Keywords: Tunca River, Water quality, Coliform bacteria, Environmental condition, Physicochemical features

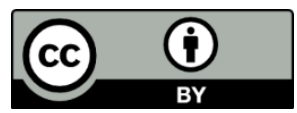

CCopyright 2020 by ScientificWebJournals Available online at 


\section{Introduction}

Rivers are recipient areas that can be easily contaminated from environmental pollutants. The negative conditions from both continental and atmospheric environments can instantly reflected by these ecosystems (Çolakoğlu \& Çakır, 2004; Bernot \& Dodds, 2005). Although the studies on composition and abundance of microorganisms in biosphere have a lot of significance, in recent years it was also the investigations of bacteria in aquatic ecosystems have got an increasing significance (Jamieson et al., 2003; Hunt \& Sarihan, 2004; Agbogu et al., 2006; Niemi \& Raateland, 2007; Sabae \& Rabeh, 2007; Mishra \& Batt, 2008; Suneela et al., 2008; Mishra et al., 2009, 2010; Saha et al., 2009; Bulut et al., 2010; Kumar et al., 2010; Venkatesharaju et al., 2010; Nguyen et al., 2016; Islam et al., 2017; Alves et al., 2018; Loucif et al., 2020). A lot of study is also carried out in our country. Çolakoğlu \& Çakır (2004) attempt to investigate physicochemical and bacteriological quality of water in the Sarıçay stream. They investigated total mesophilic aerobic bacteria, total coliform, Pseudomonas, Enterobacteriaceae, Staphylococcus, Lactobacillus, Enterococcus and yeast-mold abundance. Physical, chemical and microbiological aspects of the aquatic ecosystem were measured in Manyas Lake by Karafistan \& Colakoglu-Arik (2005). They performed total and fecal coliform bacteria, Escherichia coli, Enterococcus, Staphylococcus, Lactobasillus and Pseudomonas analysis. Toroğlu et al. (2006) were carried out total mesophilic aerobic bacteria, total coliform and fecal coliform bacteria analyzes in Aksu Stream. The physicochemical and microbiological parameters were investigated in the Karanfillicay (Bulut et al., 2010) and Egirdir Lake (Bulut et al., 2016). In these studies water samples were taken for total mesophilic aerobic bacteria, total coliform, fecal coliform and Escherichia coli analyzes. Koloren et al. (2011) evaluated the total coliform, fecal coliform, Escherichia coli and Clostridium perfringens levels in Gaga Lake.

Tunca River (Tundzha in Bulgarian) which is born in Bulgaria has $384 \mathrm{~km}$ length and it enters Turkey from Edirne province. This running water joins Meric River (Maritsa in Bulgarian; Evros in Greek) which is one of the most important tributary of Meric-Ergene River Basin and it is a boundary river between Turkey and Greece. Although there are some studies at Bulgarian and Turkish segments of Tunca
River (Uzunov, 1980; Russev et al., 1984; Janeva \& Russev, 1985; Uzunov \& Kapustina, 1993; Kavaz, 1997; Uluçam, 1997; Öterler, 2003; Kirgiz et al., 2005; Camur-Elipek et al., 2006; Sakcali et al., 2009; Georgieva et al., 2010; Vassilev et al., 2010; Aytas et al., 2014), there is no study on correlation between environmental conditions and bacteriological features in the river. In the present study, ecological status of Tunca River was evaluated using the environmental properties and bacterial features from autochthonic and allochthonic environments.

\section{Material and Methods}

The samplings were made at 5 different stations chosen from Tunca River (Figure 1) between October 2010 and September 2011 at monthly intervals. The water samples for bacterial investigation were taken from $30 \mathrm{~cm}$ beneath of the water surface and were put into $100 \mathrm{~mL}$ sterile sampling bottles under aseptic conditions and were brought to the laboratory under the condition of cold chain system. The total mesophilic aerobic bacteria (TMAB) numbers were determined by using spread plates method, while the others (total coliform, fecal coliform, and $E$. coli bacterial numbers) were determined by using Most Probable Number (MPN) method (Halkman, 2005). The culture media and incubation conditions were presented at Table 1. Nansen water sampler was used to take the water samples and the material was carried to the laboratory in lightproof bottles to analyze the physicochemical features (Egemen \& Sunlu, 1999). Spearman's correlation index was used in order to determine the effects of physicochemical conditions on TMAB numbers (Krebs, 1999). Sediment and water samples were also taken at seasonally intervals to determine some heavy metal contents (iron, copper, zinc, lead, cadmium) and the concentrations were measured by using graphite-furnace atomic absorption spectroscopy (Erçal, 2007).

\section{Results and Discussion}

The data obtained from bacteriological analysis in Tunca River were presented at Table 2, and the data of physicochemical parameters were presented at Tables 3 and 4 . 


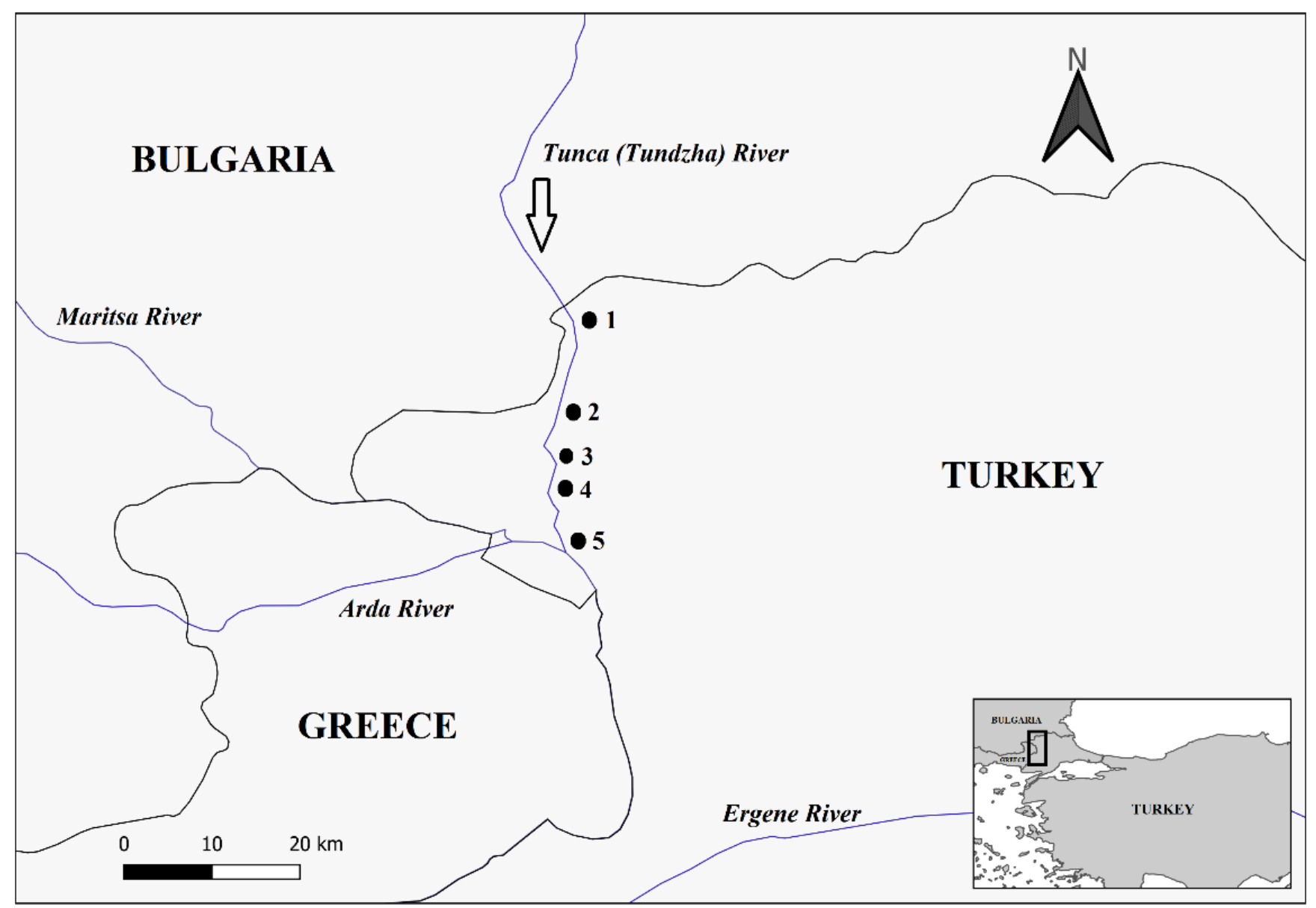

Figure 1. Location of Tunca River and the sampling stations

Table 1. Culture media and incubation conditions on growth of Microorganisms

\begin{tabular}{llll}
\hline Microorganisms & Culture Media & Temperature & Times \\
\hline TMAB & PCA & $35 \pm 0.5^{\circ} \mathrm{C}$ & $24 \pm 2$ hours \\
\hline Total Coliforms & LST Broth & $35 \pm 0.5^{\circ} \mathrm{C}$ & $24 \pm 2$ hours \\
\hline Fecal Coliforms & LST Broth & $35 \pm 0.5^{\circ} \mathrm{C}$ & $24 \pm 2$ hours \\
& EC Broth & $44.5 \pm 0.2^{\circ} \mathrm{C}$ & $24 \pm 2$ hours \\
\hline Esherichia coli & LST Broth & $35 \pm 0.5^{\circ} \mathrm{C}$ & $24 \pm 2$ hours \\
& EC Broth & $44.5 \pm 0.2^{\circ} \mathrm{C}$ & $24 \pm 2$ hours \\
& EMB Agar & $35 \pm 0.5^{\circ} \mathrm{C}$ & $24 \pm 2$ hours \\
& Tryptone Broth & $35 \pm 0.5^{\circ} \mathrm{C}$ & $24 \pm 2$ hours \\
& MR-VP Broth & $35 \pm 0.5^{\circ} \mathrm{C}$ & $24-48$ hours \\
& Simmon's Citrate Agar & $35 \pm 0.5^{\circ} \mathrm{C}$ & $24 \pm 2$ hours \\
\hline
\end{tabular}


Table 2. The numbers of bacteria determined from Tunca River

\begin{tabular}{|c|c|c|c|c|c|}
\hline & ST. 1 & ST. 2 & ST. 3 & ST. 4 & ST. 5 \\
\hline \multicolumn{6}{|c|}{ Total Mesophilic Aerobic Becteria (cfu/100mL) } \\
\hline October & $1.25 \times 10^{5}$ & $1.68 \times 10^{5}$ & $1.97 \times 10^{5}$ & $1.91 \times 10^{5}$ & $1.63 \times 10^{5}$ \\
\hline November & $6.2 \times 10^{4}$ & $1.24 \times 10^{5}$ & $2.1 \times 10^{5}$ & $3.04 \times 10^{5}$ & $2.95 \times 10^{5}$ \\
\hline December & $3.6 \times 10^{4}$ & $9.1 \times 10^{4}$ & $7.6 \times 10^{4}$ & $1.02 \times 10^{5}$ & $1.66 \times 10^{5}$ \\
\hline January & $6.9 \times 10^{4}$ & $8.6 \times 10^{4}$ & $8.2 \times 10^{4}$ & $6.7 \times 10^{4}$ & $8.1 \times 10^{4}$ \\
\hline February & $5.4 \times 10^{4}$ & $6.6 \times 10^{4}$ & $4.8 \times 10^{4}$ & $6.5 \times 10^{4}$ & $7.6 \times 10^{4}$ \\
\hline March & $4.8 \times 10^{4}$ & $5.9 \times 10^{4}$ & $4.6 \times 10^{4}$ & $8.7 \times 10^{4}$ & $1.07 \times 10^{5}$ \\
\hline April & $6.7 \times 10^{4}$ & $6.4 \times 10^{4}$ & $9.6 \times 10^{4}$ & $3.44 \times 10^{5}$ & $2.01 \times 10^{5}$ \\
\hline May & $5.3 \times 10^{4}$ & $1.48 \times 10^{5}$ & $1.65 \times 10^{5}$ & $2.34 \times 10^{5}$ & $1.5 \times 10^{5}$ \\
\hline June & $2.9 \times 10^{5}$ & $5.5 \times 10^{5}$ & $7.3 \times 10^{5}$ & $5.2 \times 10^{5}$ & $4.8 \times 10^{5}$ \\
\hline July & $4.5 \times 10^{5}$ & $1.0 \times 10^{6}$ & $4.0 \times 10^{5}$ & $6.0 \times 10^{5}$ & $5.9 \times 10^{5}$ \\
\hline August & $1.7 \times 10^{5}$ & $2.0 \times 10^{5}$ & $3.1 \times 10^{5}$ & $4.8 \times 10^{5}$ & $7.7 \times 10^{5}$ \\
\hline September & $1.6 \times 10^{5}$ & $3.4 \times 10^{5}$ & $3.8 \times 10^{5}$ & $5.2 \times 10^{5}$ & $4.2 \times 10^{5}$ \\
\hline \multicolumn{6}{|c|}{ Total Coliform (MNP/100mL) } \\
\hline October & $2.1 \times 10^{3}$ & $2.3 \times 10^{3}$ & $1.5 \times 10^{3}$ & $9.2 \times 10^{2}$ & $9.3 \times 10^{3}$ \\
\hline November & $<3.0 \times 10^{2}$ & $2.3 \times 10^{3}$ & $1.5 \times 10^{3}$ & $1.5 \times 10^{4}$ & $1.1 \times 10^{5}$ \\
\hline December & $9.2 \times 10^{2}$ & $4.3 \times 10^{3}$ & $9.2 \times 10^{2}$ & $9.3 \times 10^{3}$ & $2.4 \times 10^{4}$ \\
\hline January & $2.3 \times 10^{3}$ & $7.5 \times 10^{3}$ & $4.3 \times 10^{3}$ & $1.1 \times 10^{5}$ & $2.1 \times 10^{4}$ \\
\hline February & $4.3 \times 10^{3}$ & $4.3 \times 10^{3}$ & $2.8 \times 10^{3}$ & $1.1 \times 10^{5}$ & $7.5 \times 10^{3}$ \\
\hline March & $<3.0 \times 10^{2}$ & $9.3 \times 10^{3}$ & $9.2 \times 10^{2}$ & $4.6 \times 10^{4}$ & $2.3 \times 10^{3}$ \\
\hline April & $3.6 \times 10^{2}$ & $2.3 \times 10^{3}$ & $3.6 \times 10^{2}$ & $9.3 \times 10^{3}$ & $1.1 \times 10^{5}$ \\
\hline May & $<3.0 \times 10^{2}$ & $7.4 \times 10^{2}$ & $9.2 \times 10^{2}$ & $9.3 \times 10^{3}$ & $1.1 \times 10^{5}$ \\
\hline June & $7.4 \times 10^{2}$ & $9.3 \times 10^{3}$ & $7.4 \times 10^{2}$ & $4.6 \times 10^{4}$ & $2.4 \times 10^{4}$ \\
\hline July & $2.3 \times 10^{3}$ & $4.6 \times 10^{4}$ & $2.8 \times 10^{3}$ & $>1.1 \times 10^{7}$ & $4.6 \times 10^{4}$ \\
\hline August & $<3.0 \times 10^{2}$ & $9.3 \times 10^{3}$ & $1.5 \times 10^{3}$ & $1.5 \times 10^{4}$ & $1.5 \times 10^{4}$ \\
\hline September & $<3.0 \times 10^{2}$ & $9.2 \times 10^{2}$ & $4.6 \times 10^{4}$ & $2.4 \times 10^{4}$ & $7.5 \times 10^{3}$ \\
\hline \multicolumn{6}{|c|}{ Fecal Coliform (MPN/100mL) } \\
\hline October & $9.2 \times 10^{2}$ & $2.3 \times 10^{3}$ & $1.5 \times 10^{3}$ & $9.2 \times 10^{2}$ & $9.3 \times 10^{3}$ \\
\hline November & $<3.0 \times 10^{2}$ & $2.3 \times 10^{3}$ & $9.2 \times 10^{2}$ & $1.5 \times 10^{4}$ & $1.1 \times 10^{5}$ \\
\hline December & $9.2 \times 10^{2}$ & $4.3 \times 10^{3}$ & $3.6 \times 10^{2}$ & $9.3 \times 10^{3}$ & $2.4 \times 10^{4}$ \\
\hline January & $2.3 \times 10^{3}$ & $4.3 \times 10^{3}$ & $4.3 \times 10^{3}$ & $4.6 \times 10^{4}$ & $2.1 \times 10^{4}$ \\
\hline February & $1.5 \times 10^{3}$ & $4.3 \times 10^{3}$ & $2.1 \times 10^{3}$ & $1.1 \times 10^{5}$ & $7.5 \times 10^{3}$ \\
\hline March & $<3.0 \times 10^{2}$ & $2.1 \times 10^{3}$ & $9.2 \times 10^{2}$ & $1.5 \times 10^{4}$ & $2.3 \times 10^{3}$ \\
\hline April & $3.6 \times 10^{2}$ & $2.3 \times 10^{3}$ & $3.6 \times 10^{2}$ & $9.3 \times 10^{3}$ & $1.1 \times 10^{5}$ \\
\hline May & $<3.0 \times 10^{2}$ & $7.4 \times 10^{2}$ & $9.2 \times 10^{2}$ & $9.3 \times 10^{3}$ & $1.1 \times 10^{5}$ \\
\hline June & $7.4 \times 10^{2}$ & $9.3 \times 10^{3}$ & $3.6 \times 10^{2}$ & $4.6 \times 10^{4}$ & $2.4 \times 10^{4}$ \\
\hline July & $2.3 \times 10^{3}$ & $9.3 \times 10^{3}$ & $2.0 \times 10^{3}$ & $1.5 \times 10^{4}$ & $1.5 \times 10^{4}$ \\
\hline August & $<3.0 \times 10^{2}$ & $9.3 \times 10^{3}$ & $9.2 \times 10^{2}$ & $1.5 \times 10^{4}$ & $9.3 \times 10^{3}$ \\
\hline September & $<3.0 \times 10^{2}$ & $9.2 \times 10^{2}$ & $2.4 \times 10^{4}$ & $2.4 \times 10^{4}$ & $7.5 \times 10^{3}$ \\
\hline \multicolumn{6}{|c|}{ E. coli $(\mathrm{MPN} / 100 \mathrm{~mL})$} \\
\hline October & $9.2 \times 10^{2}$ & $2.3 \times 10^{3}$ & $7.4 \times 10^{2}$ & $9.2 \times 10^{2}$ & $9.3 \times 10^{3}$ \\
\hline November & $<3.0 \times 10^{2}$ & $2.3 \times 10^{3}$ & $9.2 \times 10^{2}$ & $1.5 \times 10^{4}$ & $1.1 \times 10^{5}$ \\
\hline December & $9.2 \times 10^{2}$ & $4.3 \times 10^{3}$ & $3.6 \times 10^{2}$ & $9.3 \times 10^{3}$ & $2.4 \times 10^{4}$ \\
\hline January & $2.3 \times 10^{3}$ & $4.3 \times 10^{3}$ & $4.3 \times 10^{3}$ & $4.6 \times 10^{4}$ & $2.1 \times 10^{4}$ \\
\hline February & $1.5 \times 10^{3}$ & $4.3 \times 10^{3}$ & $2.1 \times 10^{3}$ & $1.1 \times 10^{5}$ & $7.5 \times 10^{3}$ \\
\hline March & $<3.0 \times 10^{2}$ & $2.1 \times 10^{3}$ & $9.2 \times 10^{2}$ & $1.5 \times 10^{4}$ & $2.3 \times 10^{3}$ \\
\hline April & $3.6 \times 10^{2}$ & $2.3 \times 10^{3}$ & $3.6 \times 10^{2}$ & $9.3 \times 10^{3}$ & $1.1 \times 10^{5}$ \\
\hline May & $<3.0 \times 10^{2}$ & $7.4 \times 10^{2}$ & $9.2 \times 10^{2}$ & $2.1 \times 10^{3}$ & $1.1 \times 10^{5}$ \\
\hline June & $7.4 \times 10^{2}$ & $9.3 \times 10^{3}$ & $3.6 \times 10^{2}$ & $4.6 \times 10^{4}$ & $2.4 \times 10^{4}$ \\
\hline July & $2.3 \times 10^{3}$ & $9.3 \times 10^{3}$ & $2.0 \times 10^{3}$ & $1.5 \times 10^{4}$ & $1.5 \times 10^{4}$ \\
\hline August & $<3.0 \times 10^{2}$ & $9.3 \times 10^{3}$ & $9.2 \times 10^{2}$ & $7.5 \times 10^{3}$ & $4.3 \times 10^{3}$ \\
\hline September & $<3.0 \times 10^{2}$ & $9.2 \times 10^{2}$ & $9.3 \times 10^{3}$ & $2.4 \times 10^{4}$ & $7.5 \times 10^{3}$ \\
\hline
\end{tabular}

(ST:station; cfu:colony forming unit; MPN:most probable number) 
Table 3. Annual average values of physicochemical properties of the water samples in Tunca River

\begin{tabular}{|c|c|c|c|c|c|c|}
\hline PARAMETERS & ST. 1 & ST. 2 & ST. 3 & ST. 4 & ST. 5 & Mean \\
\hline Water temp $\left({ }^{\circ} \mathrm{C}\right)$ & 14.5 & 14.5 & 14.6 & 14.7 & 15.4 & 14.7 \\
\hline Air temp $\left({ }^{\circ} \mathrm{C}\right)$ & 14.5 & 15 & 15.3 & 15.1 & 16.2 & 15.2 \\
\hline pH & 8.92 & 8.52 & 8.41 & 8.41 & 8.31 & 8.51 \\
\hline $\mathrm{EC}(\boldsymbol{\mu S} / \mathbf{c m})$ & 549 & 556 & 568 & 574 & 574 & 564 \\
\hline DO $(\mathrm{mg} / \mathrm{L})$ & 5.83 & 5.80 & 5.50 & 5.64 & 5.45 & 5.64 \\
\hline Turbidity (cm) & 60 & 61 & 62 & 63 & 64 & 62 \\
\hline Salinity (\%o) & 0.088 & 0.086 & 0.081 & 0.087 & 0.088 & 0.086 \\
\hline Chlorides (mg/L) & 37.82 & 40.23 & 40.90 & 41.32 & 41.65 & 40.38 \\
\hline $\mathrm{H}_{2} \mathrm{~S}(\mathrm{mg} / \mathrm{L})$ & 0.284 & 0.461 & 0.497 & 0.337 & 0.550 & 0.425 \\
\hline $\mathrm{Ca}^{+2}(\mathrm{mg} / \mathrm{L})$ & 61.05 & 62.65 & 60.78 & 58.55 & 56.51 & 59.90 \\
\hline $\mathrm{Mg}^{+2}(\mathrm{mg} / \mathrm{L})$ & 15.44 & 17.78 & 18.15 & 18.76 & 18.67 & 17.76 \\
\hline Total hardness $\left(\mathrm{FS}^{\circ}\right)$ & 17.0 & 18.3 & 17.6 & 17.1 & 17.1 & 17.4 \\
\hline $\mathrm{NO}_{2}-\mathrm{N}(\mathrm{mg} / \mathrm{L})$ & 0.023 & 0.021 & 0.023 & 0.024 & 0.026 & 0.023 \\
\hline $\mathrm{NO}_{3}-\mathrm{N}(\mathrm{mg} / \mathrm{L})$ & 5.648 & 5.859 & 5.389 & 6.708 & 6.621 & 6.045 \\
\hline Phosphate (mg/L) & 0.056 & 0.055 & 0.057 & 0.060 & 0.057 & 0.057 \\
\hline Sulphate (mg/L) & 2.013 & 2.104 & 2.212 & 2.204 & 2.203 & 2.147 \\
\hline SSS (mg/L) & 302 & 295 & 320 & 345 & 394 & 331 \\
\hline
\end{tabular}

(ST:station; EC:conductivity, DO:dissolved oxygen, SSS:suspended solid substances)

The highest average values for the TMAB numbers in Tunca River was recorded as $6.08 \times 10^{5} \mathrm{cfu} / 100 \mathrm{~mL}$ at month July. Also, it was found that the increasing of TMAB numbers in the summer and the autumn was remarkable (Table 2). Çolakoğlu \& Çakır (2004) reported that, in summer and autumn, most diversification of bacteria was observed. This situation can be explained by rising of water temperature in summer season and decreasing of flow, and increasing of organic substances which has been joined the water because of rain fall in autumn (Elmac1 et al., 2008; Mishra et al., 2009; Saha et al., 2009; Bulut et al., 2010). Koloren et al. (2011) reported that the number of indicator bacteria and rain fall is directly proportional. Bulut et al. (2016) reported that TMAB ranged between with 0 to $172 \mathrm{cfu} / 100 \mathrm{~mL}$ in Egirdir Lake. TMAB in the Golbasi Lake was determined as $20 \times 10^{3} \mathrm{cfu} / \mathrm{mL}$ (Toroglu \& Toroglu, 2009). In our study, TMAB ranged between $3.6 \times 10^{4}-1.0 \times 10^{6} \mathrm{cfu} / 100 \mathrm{~mL}$. When the total coliform, fecal coliform, and E. coli bacterial numbers were evaluated considering the sampling stations, the highest values were recorded in the $4^{\text {th }}$ and $5^{\text {th }}$ stations which are located near to city center of Edirne Province (Table 2), but the $1^{\text {st }}$ station which is the most away from city center has been observed to be has the least bacteriological numbers. These high values can be explained by the sewages enter to the river from the $4^{\text {th }}$ and $5^{\text {th }}$ stations. Although, Karafistan \& Colakoglu-Arik
(2005) reported that Lake Manyas is threatened by anthropogenic pollution. Our findings demonstrated similar results. Bulut et al. (2016) reported that E. coli was not detected at all stations in Egirdir Lake. But our findings, E. coli were found at all times and stations in Tunca River.

The water and air temperature values of Tunca River were observed at seasonal expectancy that the values range between minimum $2^{\circ} \mathrm{C}$ and maximum $28^{\circ} \mathrm{C}$ (Figure 2). Also, Spearman's index showed that a positive correlation between the TMAB numbers and temperature values (for water temperature $\mathrm{r}=0.576, \mathrm{p}<0.05$ in the autumn and $\mathrm{r}=0.571, \mathrm{p}<0.05$ in the spring; for air temperature $\mathrm{r}=0.894, \mathrm{p}<0.05$ in the April, $r=0.975, p<0.01$ in the August and $r=0.533, p<0.05$ in the autumn).

While the average values of dissolved oxygen (DO) in the river was observed as $5.64 \mathrm{mg} / \mathrm{L}$, the lowest DO levels were measured at sampling stations which are the nearest to city center. Speraman's index showed that a negative correlation between the DO values and TMAB numbers in Tunca River $(\mathrm{r}=-0.894, \mathrm{p}<0.05$ in October; $\mathrm{r}=-0.894, \mathrm{p}<0.05$ in May; $\mathrm{r}=$ $-0.949, \mathrm{p}<0.05$ in November). This situation can be explained by the organic materials found in water were decomposed by activities of aerobic microorganisms and thus oxygen consumed. Also, it was observed that the water temperature and DO have an inversely correlation in the study (Figure 2). 

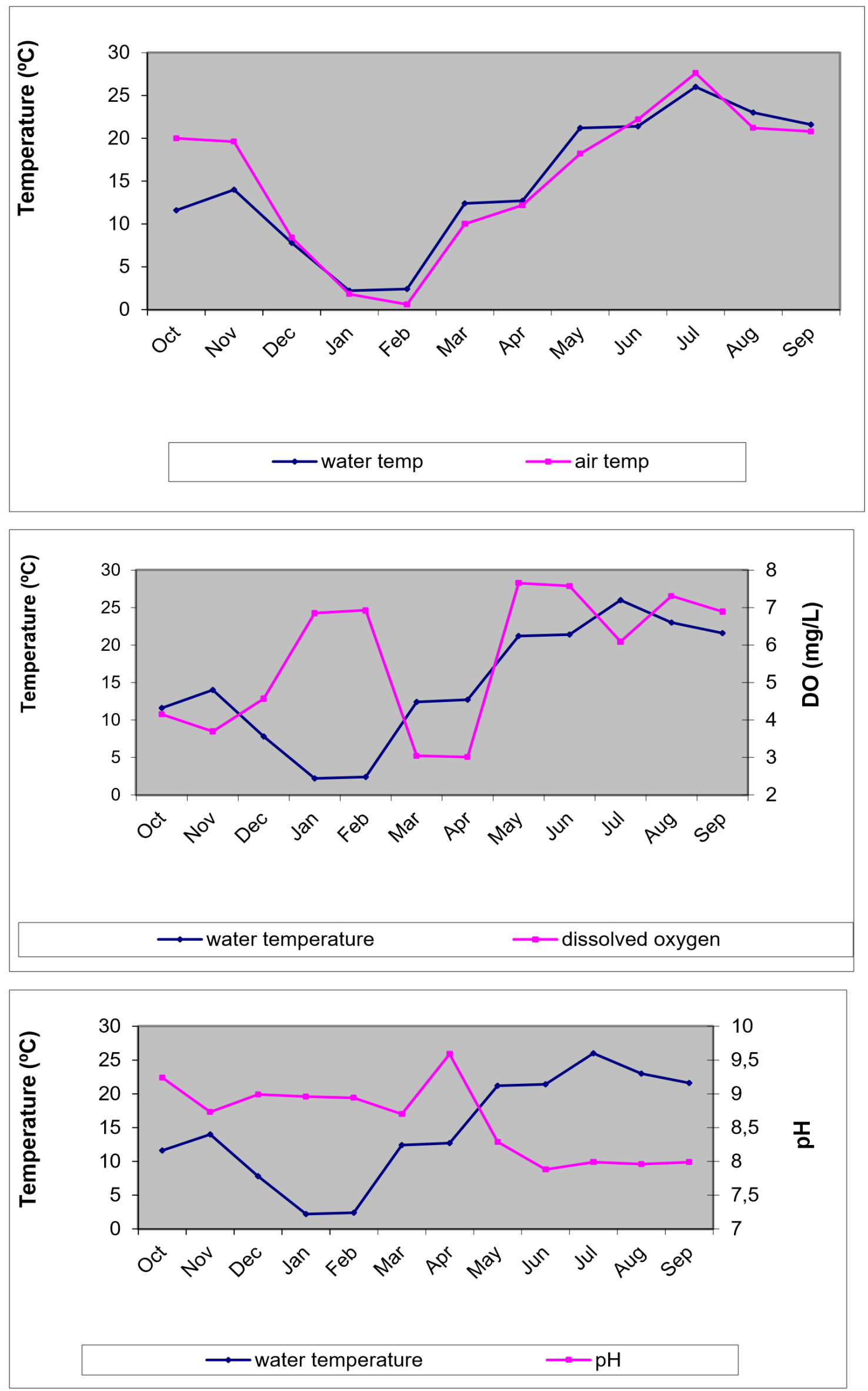


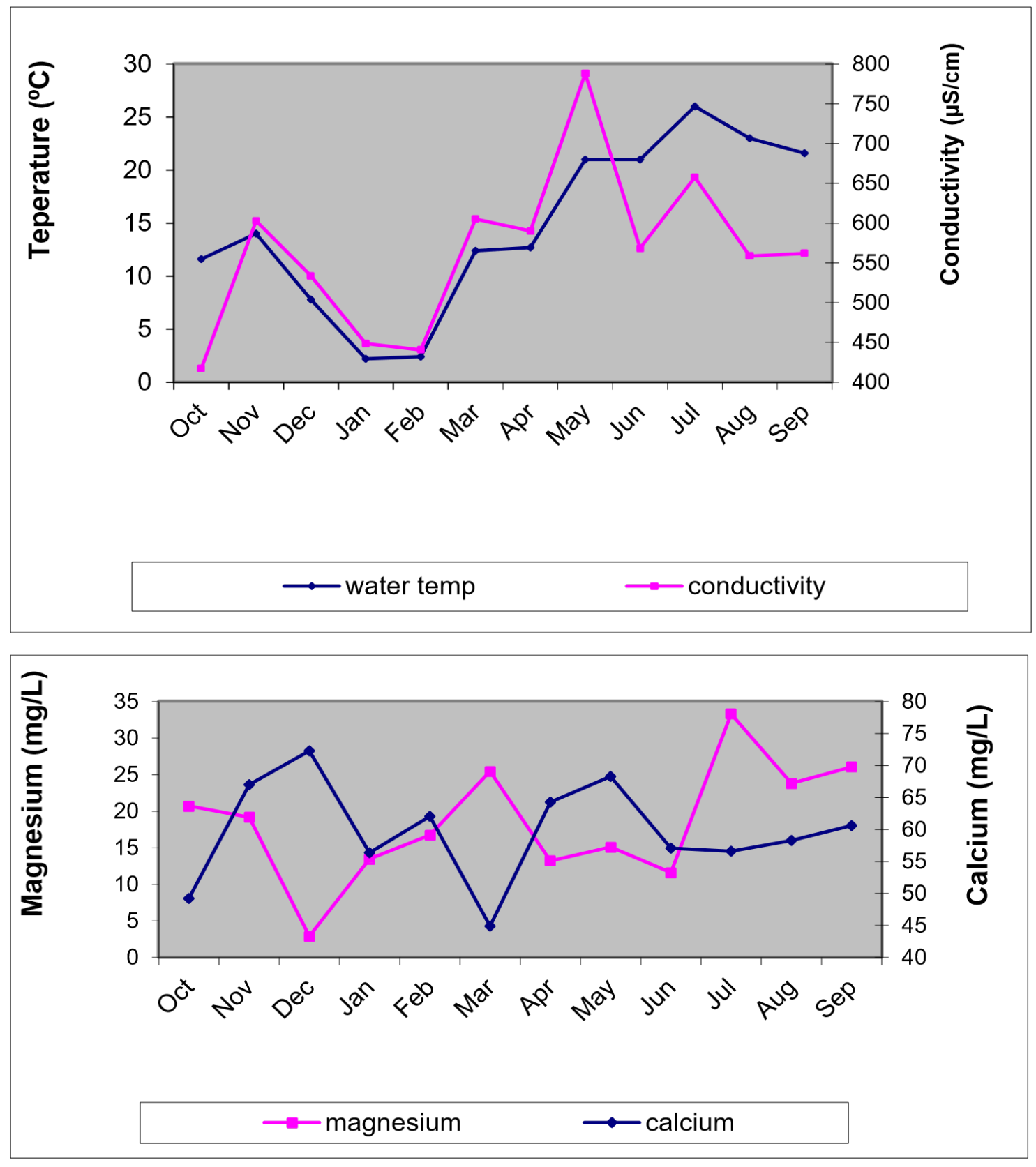

Figure 2. Monthly averages of some physicochemical parameters of Tunca River 
The $\mathrm{pH}$ values were measured to have the lowest values in summer period and the highest in winter (Figure 2). The reason of the decrease in the summer might be the decomposition of organic materials by increasing activities of microorganisms. While the $\mathrm{pH}$ values change between 7.77 and 9.98 , it was observed to have a negative correlation between the TMAB numbers and $\mathrm{pH}$ values $(\mathrm{r}=-0.900, \mathrm{p}<0.05$ in June; $r$ $=-1.000, p<0.01$ in October; $r=-0.699, p<0.01$ in autumn; $r$ $=-0.651, \mathrm{p}<0.01$ in spring).

The decreasing of conductivity (EC) values of the river at winter season can be explained by decreasing of temperature in cold months (Figure 2). The average EC values were recorded as $564 \mu \mathrm{S} / \mathrm{cm}$ and it was observed to have a positive correlation between the EC and the TMAB numbers ( $\mathrm{r}=$ $1.000, \mathrm{p}<0.01$ in August).

Although, the highest value was observed at month June, salinity levels in Tunca River did not change during the sampling periods. Excessive evaporation from surface of river and the lowest water level at month June can explain this situation.

The secchi disc depth was found to be very high in the summer because of the highest light permeability. But the secchi disc depth was measured very low at autumn season because of erosion towards to the river by the effect of rain.

The measured minimum $\mathrm{H}_{2} \mathrm{~S}$ rate was recorded in the winter season as $0.028 \mathrm{mg} / \mathrm{L}$. Activities of microorganisms decrease in winter season because of falling of water temperature, and thus $\mathrm{H}_{2} \mathrm{~S}$ values decrease, too. Furthermore, a negative correlation was observed between $\mathrm{H}_{2} \mathrm{~S}$ values and TMAB numbers in the river $(r=-0.975, p<0.01$ in October $)$.

While it was recorded that the calcium values at minimum 36.07 and maximum $76.95 \mathrm{mg} / \mathrm{L}$; the magnesium values were observed minimum 0.48 and maximum $42.13 \mathrm{mg} / \mathrm{L}$. Furthermore, an inverse correlation was determined between $\mathrm{Ca}^{+2}$ and $\mathrm{Mg}^{+2}$ levels in the river (Figure 2). Also, a negative correlation was observed between TMAB numbers and $\mathrm{Ca}^{+2}$ values $(\mathrm{r}=-1.000, \mathrm{p}<0.01$ in December $)$; and a positive correlation between TMAB numbers and $\mathrm{Mg}^{+2}$ values $(\mathrm{r}=0.533$, $\mathrm{p}<0.05$ in autumn).

Annual mean total hardness (TH) in Tunca River was measured as $17.4 \mathrm{FH}^{\circ}$. A negative correlation was determined between $\mathrm{TH}$ value and TMAB numbers (in June $\mathrm{r}=-0.894$, $\mathrm{p}<0.05$; in winter $\mathrm{r}=-0.740, \mathrm{p}<0.01$; in spring $\mathrm{r}=-0.651$, $\mathrm{p}<0.01)$.

The average nitrite nitrogen values were recorded as 0.023 $\mathrm{mg} / \mathrm{L}$ in Tunca River. This value showed that the river has beta-mezosaprobic level towards to alfamezosaphrobic (Kazanc1 \& Dugel, 2009). The maximum values belonging nitrite nitrogen were measured as $0.143 \mathrm{mg} / \mathrm{L}$ in November. The reason of this increase in November might be explained because of decrease bacterial activities transforming nitrite to nitrate by the intermediate product of nitrification with the temperature falling. In this study, the average nitrate nitrogen values were recorded as $13.969 \mathrm{mg} / \mathrm{L}$ with the highest ratio in May. This value showed that the river has beta-mezosaprobic level (Kazanc1 \& Dugel, 2009). Furthermore, a positive correlation was found between $\mathrm{NO}_{3}-\mathrm{N}$ values and TMAB numbers $(\mathrm{r}=$ $0.575, p<0.05$ in winter). Our results on the increasing of nitrate levels in spring season are similar the results the study performed by Hunt \& Sarıhan (2004) in Saricam Stream.

The average sulfide values were measured as $2.14 \mathrm{mg} / \mathrm{L}$ in the river. Also, a positive correlation was determined between $\mathrm{SO}_{4}{ }^{-2}$ values and TMAB numbers $(\mathrm{r}=0.975, \mathrm{p}<0.01$ in August; $\mathrm{r}=0.900, \mathrm{p}<0.05$ in September; $\mathrm{r}=0.515, \mathrm{p}<0.05$ in summer).

It was measured the o- $\mathrm{PO}_{4}^{-3}$ (ortho-phosphate) values between minimum 0.020 and maximum $0.146 \mathrm{mg} / \mathrm{L}$, and a positive correlation was found between o- $\mathrm{PO}_{4}^{-3}$ and TMAB numbers $(r=0.975, p<0.01$ in November; $r=0.900, p<0.05$ in December; $r=0.975, p<0.01$ in July; $r=0.751, p<0.01$ in winter). The values indicated that the river has beta-mesotrophic conditions according to the o- $\mathrm{PO}_{4}^{-3}$ levels.

The values of suspended solid substances (SSS) were measured at very high levels in November with $546 \mathrm{mg} / \mathrm{L}$. Erosion material might have entered to the river by influence of rainfall, and thus the SSS values have reached to the high levels. It is seen that the data on SSS we obtained in the present study show similarity with the results of the study performed by Öterler (2003) in Tunca River. However, our findings on SSS were found to be higher than the findings from another study performed by Uluçam (1997) in the river. Furthermore, a positive correlation was determined between SSS values and TMAB numbers $(\mathrm{r}=0.900, \mathrm{p}<0.05$ in April; in September $\mathrm{r}=0.900, \mathrm{p}<0.05)$.

As it was compared with studies carried out in Tunca River in previous, it was observed that biological oxygen demand $\left(\mathrm{BOD}_{5}\right)$ values increased at time. The entering of pollutant material to the river might lead to this situation. Also, a negative correlation was found between $\mathrm{BOD}_{5}$ values and TMAB numbers $(r=-0.975, p<0.01$ in November; $r=-0.900$, $p<0.05$ in May; $r=-0.900, p<0.05$ in September).

Summarized, according to Spearman's Correlation Index, positive correlations were found between TMAB density and some environmental parameters (water-air temperature, EC, magnesium, nitrate nitrogen, sulphate, o-phosphate, and suspended solids); negative correlations were found between 
TMAB density and the other parameters $(\mathrm{pH}$, hydrogen sulphide, calcium, total hardness, and $\mathrm{BOD}_{5}$ ).

The obtained data for heavy metals were shown at Table 4 . According to the observed heavy metal values, the lead concentrations were found at high level.

When the obtained data on the physicochemical variables were evaluated according to Surface Water Quality Control Regulation of Turkey (Anonymous, 2016), the water quality of Tunca River was found at first quality level in terms of some parameters (temperature, $\mathrm{pH}$, chloride, nitrate nitrogen, sulfate, phosphate, and cadmium). However, some observed parameter values ( $\mathrm{DO}$, nitrite nitrogen, iron, copper, and zinc) have signed that the river has second quality level. And the river was found at fourth quality level according to the findings of total coliform, fecalcoliform, $\mathrm{BOD}_{5}$, and lead.

\section{Conclusions}

According to the some physicochemical findings observed in this study, it was determined that the water quality of Tunca
River has proper conditions allowing surviving of living things. However, bacteriological findings belonging to the river was not found proper for direct use of water by human. Especially, the existence of E.coli in the river has shown that a serious contamination with fecal matter. Furthermore, the high levels belonging coliform, fecal coliform and E. coli indicate that the possibility the presence of other pathogenic microorganisms. Consequently, using the water of river will has been restricted by emergence of some resistant bacteria (Toroglu et al., 2006).

Consequently, it is suggested that pollution sources reaching to the river should be determined in order to remove present pollution of Tunca River or to prevent it to be more polluted. Therefore, it is also required to repeat similar analysis frequently and to follow the changes to appear in the water quality.

Table 4. Annual average values of heavy metals of the water and sediment samples in Tunca River

\begin{tabular}{|c|c|c|c|c|c|c|}
\hline $\begin{array}{l}\text { Station } \downarrow \\
\rightarrow\end{array}$ & Heavy Metals & $\mathrm{Fe}(\mathrm{mg} / \mathrm{L})$ & $\mathrm{Cu}(\mathrm{mg} / \mathrm{L})$ & Zn (mg/L) & $\mathrm{Pb}(\mathrm{mg} / \mathrm{L})$ & $\mathrm{Cd}(\mathrm{mg} / \mathrm{L})$ \\
\hline$\stackrel{r}{5}$ & $\begin{array}{l}\text { Water } \\
\text { Sediment }\end{array}$ & $\begin{array}{c}1.82 \\
78.25\end{array}$ & $\begin{array}{l}0.08 \\
1.01\end{array}$ & $\begin{array}{l}0.39 \\
1.19\end{array}$ & $\begin{array}{c}4.21 \\
57.43\end{array}$ & $\begin{array}{l}\text { ND } \\
\text { ND }\end{array}$ \\
\hline$\stackrel{N}{5}$ & $\begin{array}{l}\text { Water } \\
\text { Sediment }\end{array}$ & $\begin{array}{c}1.36 \\
91.62\end{array}$ & $\begin{array}{l}0.11 \\
1.82\end{array}$ & $\begin{array}{l}0.31 \\
2.47\end{array}$ & $\begin{array}{c}4.91 \\
61.49\end{array}$ & $\begin{array}{l}\text { ND } \\
\text { ND }\end{array}$ \\
\hline$\stackrel{m}{⺊}$ & $\begin{array}{l}\text { Water } \\
\text { Sediment }\end{array}$ & $\begin{array}{c}0.75 \\
348.20\end{array}$ & $\begin{array}{l}0.08 \\
1.51\end{array}$ & $\begin{array}{l}0.16 \\
9.23\end{array}$ & $\begin{array}{c}4.69 \\
74.05\end{array}$ & $\begin{array}{l}\text { ND } \\
\text { ND }\end{array}$ \\
\hline$\stackrel{+}{5}$ & $\begin{array}{l}\text { Water } \\
\text { Sediment }\end{array}$ & $\begin{array}{c}1.19 \\
191.41\end{array}$ & $\begin{array}{l}0.03 \\
1.98\end{array}$ & $\begin{array}{l}2.69 \\
2.56\end{array}$ & $\begin{array}{c}5.42 \\
66.64\end{array}$ & $\begin{array}{l}\text { ND } \\
\text { ND }\end{array}$ \\
\hline$\stackrel{n}{\llcorner}$ & $\begin{array}{l}\text { Water } \\
\text { Sediment }\end{array}$ & $\begin{array}{c}2.08 \\
266.96\end{array}$ & $\begin{array}{l}0.09 \\
1.85\end{array}$ & $\begin{array}{l}0.48 \\
3.56\end{array}$ & $\begin{array}{c}5.31 \\
66.64\end{array}$ & $\begin{array}{l}\text { ND } \\
\text { ND }\end{array}$ \\
\hline
\end{tabular}

(ND:not determined) 


\section{Compliance with Ethical Standard}

Conflict of interests: The authors declare that for this article they have no actual, potential or perceived conflict of interests.

Ethics committee approval: All authors declare that this study does not include any experiments with human or animal subjects.

Funding: This study is a part of first author's MsC thesis which has been supported as TUBAP-2011/15 project by Trakya University Research Fund.

Acknowledgments: -

\section{References}

Agbogu, V.N., Umoh, V.J., Okuofu, C.A., Smith, S.I., Ameh, J.B. (2006). Study of the bacteriological and physicochemical indicators of pollution of surface waters in Zaria, Nigeria. African Journal of Biotechnology, 5(9), 732-737.

Alves, R.I., Machado, C.S., Beda, C.F., Fregonesi, B.M., Nadal, M., Sierra, J., Domingo, J.L., Segura-Muñoz, S.I. (2018). Water quality assessment of the Pardo River Basin, Brazil: a multivariate approach using limnological parameters, metal concentrations and indicator bacteria. Archives of Environmental Contamination and Toxicology, 75(2), 199212.

https://doi.org/10.1007/s00244-017-0493-7

Anonymous (2016). Surface water quality control regulation. Official Gazette No: 29797 of 10 August 2016, Ankara.

Aytas, S., Erenturk, S., Aslani, M.A.A., Yusan, S., Turkozu, D.A. Gok, C., Karali, T., Gokce, M., Oguz, K.F. (2014). Determination and evaluation of natural radioactivity and heavy metal levels in the aquatic environment of transboundary rivers: Maritza, Tundja and Arda. Journal of Radioanalytical and Nuclear Chemistry, 300, 933-945.

https://doi.org/10.1007/s10967-014-3091-4

Bernot, M.J., Dodds, W.K. (2005). Nitrogen retention, removal, and saturation in lotic ecosystems. Ecosystems, 8, 442-453.

https://doi.org/10.1007/s10021-003-0143-y

Bulut, C., Akçimen, U., Uysal, K., Küçükkara, R., Savaşer, S. (2010). Seasonal variations of physicochemical and microbiological parameters of the Karanfilli Cay creek water and its aquacultural evaluation. Dumlupinar University Journal of Natural Sciences, 21, 1-7.
Bulut, C., Kubilay, A., Akçimen, U., Yener, O. (2016). Seasonal changes of microbiology quality in Egirdir Lake. Süleyman Demirel University Journal of Natural and Applied Sciences, 20(1), 50-53.

Camur-Elipek, B., Arslan, N., Kirgiz, T., Oterler, B. (2006). Benthic macrofauna in Tunca River (Turkey) and their relationships with environmental variables. Acta $\mathrm{Hy}$ drochimica Hydrobiologica, 34(4), 360-366.

https://doi.org/10.1002/aheh.200500631

Çolakoğlu, F., Çakır, F. (2004). Microbiological quality of Sarıcay. Turkish Journal of Aquatic Life, 2(3), 320-327.

Egemen, O., Sunlu, U. (1999). Water quality. Ege University Fisheries Faculty Issue number: 14, İzmir. 148pp. ISBN: 975-483-141-6.

Elmacı, A., Teksoy, A., Topaç, F.O., Özengin, N., Başkaya, H.S. (2008). Monitoring of seasonal variation of microbial quality in Lake Ulubat. Uludag University Journal of The Faculty of Engineering and Architecture, 13(1), 93103.

Erçal, E. (2007). The observing of the heavy metal pollution in the gulfs of the Northern Cyprus Güzelyurt, Girne and Magusa. Marmara University, Institute of Natural Sciences, Master Thesis. 82pp.

Georgieva, N., Yaneva, Z., Dospatliev, L. (2010). Analyses of natural water quality in Stara Zagora region according to the parameters sulfates and chlorides. Trakia Journal of Sciences, 8(2), 517-524.

Halkman, K. (2005). Merck food microbiology applications. Basak Printhouse Ltd. Sti., Ankara. 358pp. ISBN 975-00373$0-8$

Hunt, A.O., Sarihan, E. (2004). Physico-chemical and bacteriological features on Sarıçam stream which is a branch of the Seyhan River. Journal of Egirdir Fisheries Faculty, 12(2), 51-58.

Islam, M.M., Hofstra, N., Islam, M.A. (2017). The impact of environmental variables on fecalindicator bacteria in the Betna river basin, Bangladesh. Environmental Processes, 4(2), 319-332.

https://doi.org/10.1007/s40710-017-0239-6 
Jamieson, R.C., Gordon, R.J., Tattrie, S.C., Stratton, G.W. (2003). Sources and persistence of fecal coliform bacteria in a rural watershed. Water Quality Research Journal of Canada, 38(1), 33-47.

https://doi.org/10.2166/wqri.2003.004

Janeva, I.J., Russev, B.K. (1985). Trends in changes of the hydrobiological and saprobiological state of the Tundzha River. II. May-November 1981. Hydrobiology (Sofia), 26, $15-36$.

Karafistan, A., Colakoglu-Arik, F. (2005). Physical, chemical and microbiological water quality of the Manyas Lake, Turkey. Mitigation and Adaptation Strategies for Global Change, 10, 127-143.

https://doi.org/10.1007/s11027-005-7835-x

Kavaz, E. (1997). Benthic macroinvertebrate fauna of Tunca River. Trakya University, Institute of Natural Sciences, Master Thesis. 38pp.

Kirgiz, T., Camur, B., Arslan, N. (2005). Preliminary study of Enchytraeidae (Oligochatea) in Tunca River. Proceedings of the Estonian Academy of Sciences: Biology/Ecology, 54(4), 310-314.

Koloren, Z., Taş, B., Kaya, D. (2011). Microbiological pollution of Gaga Lake in Ordu (Turkey), The Black Sea Journal of Sciences, 2(1), 74-85.

Krebs, J.C. (1999). Ecological methodology. Addison Wesley Longman, Inc., Menlo Park, California. ISBN: $0321021738 / 9780321021731$

Kumar, A., Bisht, B.S., Joshi, V.D., Singh, A.K., Talwar, A. (2010). Physical, chemical and bacteriological study of water from rivers of Uttarakhand. Journal of Human Ecology, 32(3), 169-173.

https://doi.org/10.1080/09709274.2010.11906336

Loucif, K., Neffar, S., Menasria, T., Maazi, M. C., Houhamdi, M., Chenchouni, H. (2020). Physico-chemical and bacteriological quality assessment of surface water at Lake Tonga in Algeria. Environmental Nanotechnology, Monitoring \& Management, 13, 100284.

https://doi.org/10.1016/j.enmm.2020.100284

Mishra, A., Bhatt, V. (2008). Physico-chemical and microbiological analysis of under ground water in V.V Nagar and near by places of Anand District, Gujarat, India. E-Journal of Chemistry, 5(3), 487-492. https://doi.org/10.1155/2008/671978

Mishra, A., Bhatt, V.D., Sevak, N., Shah, P., Patel, K., Patel, C. (2010). Comparative study of physico-chemical and microbial parameters on lotic and ground-waters in selected outlying areas of central Gujarat. Journal of Chemical and Pharmaceutical Research, 2(4), 174-177.

Mishra, A., Mukherjee, A., Tripathi, B.D. (2009). Seasonal and temporal variations in physicochemical and bacteriological characteristics of River Ganga in Varanasi. International Journal of Environmental Research, 3(3), 395-402.

Nguyen, H.T.M., Le, Q.T.P., Garnier, J., Janeau, J. L., Rochelle-Newall, E. (2016). Seasonal variability of fecalindicator bacteria numbers and die-off rates in the Red River basin, North Vietnam. Scientific Reports, 6, 21644.

https://doi.org/10.1038/srep21644

Niemi, J., Raateland, A. (2007). River water quality in the Finnish Eurowaternet. Boreal Environment Research, 12, 571-584.

Öterler, B. (2003). An investigation on Tundza River phytoplancton and their relationships with water quality. Trakya University, Institute of Natural Sciences, Master Thesis. 68pp.

Russev, B.K., Nikolova, M.I., Dimitrova, M.A. (1984). Hydrobiological and saprobiological alterations in The Tundzha River. I. 1995-1967. Hydrobiology (Sofia), 22, 59-73.

Sabae, Z.S., Rabeh, A.S. (2007). Evaluation of the microbial quality of the River Nile waters at Damietta Branch, Egypt. Egyptian Journal of Aquatic Research, 33(1), 301311.

Saha, M.L., Khan, M.R., Ali, M., Hoque, S. (2009). Bacterial load and chemical pollution level of the River Buriganga. Bangladesh Journal of Botany, 38(1), 87-91. https://doi.org/10.3329/bjb.v38i1.5128

Sakcali, M. S., Yilmaz, R., Gucel, S., Yarci, C., Ozturk, M. (2009). Water pollution studies in the Rivers of Edirne Region. Aquatic Ecosystem Health \& Management, 12(3), 313-319.

https://doi.org/10.1080/14634980903133757

Suneela, M., Krishna, G.R., Krishna, K.V., Sai, V.M., Bhargav, V., Reddy, K.S., Srinivas, D.S.S., Srinivas, J.S. (2008). Water and sediment analysis of Hussain Sagar Lake, 
Hyderabad, Proceeding of Taal 2007. The 12th World Lake Conference, 304-306.

Toroğlu, E., Toroğlu, S. (2009). Microbial pollution of water in Golbasi Lake in Adiyaman Turkey. Journal of Environmental Biology, 30(1), 33-38.

Toroğlu, E., Toroğlu, S., Alaeddinoğlu, F. (2006). Water pollution in the Aksu River (Kahraman Maras). Turkish Journal of Geographical Sciences, 4(1), 93-103.

Uluçam, G. (1997). Investigate a proper purification method for domestic and industrial wastes in Tunca River (in Turkish with English Abstract). Trakya University, Institute of Natural Sciences, Master Thesis. 153pp.

Uzunov, J.I. (1980). Water Oligochets (Oligochaeta, Limicola) from some Bulgarian rivers. Frequency and Domination, Hydrobiology, 12, 79-89.
Uzunov, Y., Kapustina, L. (1993). Current review on Oligochaeta from macrozoobenthic communities of the Bulgarian rivers. Lauterbornia, 13, 73-83.

Vassilev, M., Apostolou, A., Velkov, B., İvanova, P., Panayotova, M., Dobrev, D., Pehlivanov, L. (2010). Status of Gobiid ichtyofauna (Gobiidae) in Bulgaria: Taxonomical, conservative, ecological and social aspects. Natura Montenegrina, Podgorica, 10(2), 115-124.

Venkatesharaju, K., Ravikumar, P., Somashekar, R.K., Prakash, K.L. (2010). Physico-chemical and bacteriological investigation on the River Cauvery of Kollegal Stretch in Karnataka. Kathmandu University Journal of Science, Engineering and Technology, 6(1), 50-59.

https://doi.org/10.3126/kuset.v6i1.3310 